\title{
A Conceptual Development of a Business Model Typology in Tourism: the impact of digitalization and location
}

\author{
Gabriel Linton and Christina Öberg
}

\author{
" Luck is not a business model." \\ Anthony Bourdain \\ Chef, author, and travel documentarian
}

\begin{abstract}
This paper aims to conceptually develop a business model typology in tourism. It focuses on digitalization and destination location as important contextual factors when developing the typology. The paper builds on prior research on business models and tourism research by adopting configuration theory to create a typology of business models in tourism businesses. Four business model archetypes are identified: (1) bricks and mortar business models, (2) digitalized destinations, (3) create-a-destination, and (4) intermediary business models. The typology contributes to the literature by identifying different types of business models in the tourism sector. The typology also helps to ground the business model concept theoretically, something that has been considered as missing in previous business model research.
\end{abstract}

\section{Introduction}

Technological development within tourism has enabled a change in consumer behavior, led to the emergence of new actors entering the sector along with widespread digitalization (Boksberger \& Laesser, 2009; Laesser et al., 2009; Koukopoulos \& Styliaras, 2013; Kubiak, 2014; Wernz et al., 2014). This, in turn, has resulted in new ways of designing businesses (Burger \& Fuchs, 2005; d'Angella et al., 2010; Zach \& Racherla, 2011; Zach, 2012; Krizaj et al., 2014). Beritelli and Schegg (2016), for instance, describe online booking systems, Yu (2016) points at e-tourism, Scheepens et al. (2016) refer to sustainability initiatives, and De Carlos et al. (2016) indicate how online booking systems introduce new actors in the tourism sector, as do Kathan et al. (2016), and Forgacs and Dimanche (2016) in relation to platform-based businesses. These new business designs reflect some ongoing changes to business models in the sector (Osterwalder et al., 2005; Zott et al., 2011) and suggest the possibility of structuring different ways to operate within tourism. A business model can be defined as a system of interdependent activities of a firm, its business partners, and the mechanisms that link these activities (Zott \& Amit, 2010). In short, it is the way a firm operates its business.
The increased variety of business model designs in the tourism sector (Martins et al., 2015) draws attention to how various business models may fit in different situations and for different purposes (Zott \& Amit, 2013). Through configuration theory, it is possible to conceptually identify archetypes, or in other words, wellperforming business model configurations. The purpose of this paper is to conceptually develop a business model typology in the tourism sector. The theoretical basis for deriving a typology of business models (Baden-Fuller \& Morgan, 2010) draws on a configuration approach, which takes into account contingency factors of digitalization as well as company location. In tourism research, the location of a firm is a central theme that focuses on topics such as accessibility and attractiveness of destinations (Henderson, 2006). The location as an external factor is thereby stressed more extensively for business models in tourism than in many other sectors. Digitalization has been shown to change the way tourism operates, including intermediation and peer-topeer (P2P) sharing. Gardiner and Scott (2018), for instance, discuss how digital innovation in tourism has changed the ways companies conduct their business. 


\section{A Conceptual Development of a Business Model Typology in Tourism: the impact of digitalization and location Gabriel Linton and Christina Öberg}

The paper contributes to previous research in multiple ways. While several scholars have discussed the emergence of new business models in the tourism sector, the discussions remain quite fragmented, and no attempts have been made to structurally present these, nor to describe them in terms of individual configurations, and how the parts of the configurations fit (or align) together. From a theoretical point of view, the suggested typology provides an important and contemporary overview of business models in the sector, something which is important given the sector's ongoing development (Brannon \& Wiklund, 2014). The tourism sector is expanding based on the increased wealth and travel of individuals making it an important sector to study. Digitalization opens the way for a contemporary understanding of the sector.

The use of configuration theory to derive the typology offers a way to conceptualize business models, as well as helping to enable the theoretical grounding of business models in general (Chesbrough \& Schwartz, 2007; Johnson et al., 2008; Demil \& Lecocq, 2010; McGrath, 2010; Teece, 2010; George \& Bock, 2011; Foss \& Saebi, 2017). From a practical point of view, the typology helps to guide actors that are either in or entering the sector to design business models that fit their purposes depending on the company's technology level and location. Most previous studies on business models concern high-technology companies and collaborations among relevant stakeholders. The focus on tourism offers an opportunity to expand the empirical base for business model studies.

The next section introduces business models and the configuration approach, followed by a section that briefly discusses how digitalization and a company's location have an impact on its business model. Thereafter, various settings are discussed based on digitalization and location, along with the business models most likely to best fit each setting. The paper's theoretical contribution, managerial implications, and further research agenda are discussed in the concluding section.

\section{Theoretical Background: Business models, configuration theory, and tourism}

\subsection{Business models}

A business model refers to how a firm operates its business and is a central instrument for tourism companies. Research in the business model area is extensive, capturing both strategic and entrepreneurial discussions of business models (Zott \& Amit, 2013; Mangematin \& Baden-Fuller, 2015; Martins et al., 2015; Taran et al., 2016; Molina-Castillo et al. 2019). There are numerous ways of conceptualizing business model components. Teece (2010), for instance, refers to business models by focusing on how companies deliver value to customers, attract customers to pay for the value, and obtain profits from the value deliveries. Magretta (2002) similarly describes business models as dealing with customers, value creation, and delivery, while also including the economic logic of the company. While both Teece's (2010) and Magretta's (2002) descriptions may appear as one-sided business models that focus only on customer offerings, they also include how a company organizes its business to achieve those value offerings.

Osterwalder et al. (2005) explicitly refer to resource provisions, in addition to value created and offered to customers, thus emphasizing a holistic view of how business is operated (Bolton \& Hannon, 2016). Zott and Amit (2010), in a similar holistic way, describe activities in terms of their content, structure, and governance, including both the provision and offering of a company and its business partners. An often-denoted characteristic of business models is how they extend across company boundaries, as well as incorporating parties from various industries (Schweizer, 2005; Zott \& Amit, 2013). Chesbrough (2007), for instance, introduced the concept of open business models that focus on how multiple parties are involved in the value creation process.

This paper describes the components of a business model as activities that center around the focal company (Zott \& Amit, 2013; Heilbron \& Casadesus-Masanell, 2015; Martins et al., 2015), including the activities of business partners, customers, and vendors (Zott \& Amit, 2010). The paper follows Zott and Amit's (2010) conceptualization of business models as activity systems, where content refers to what activities are selected and performed in the business model, structure describes how those activities are linked, and governance depicts who performs the different activities.

\subsection{Configuration theory}

The notion of a business model as an activity system (Zott \& Amit, 2010) emphasizes that distinct activities in a business model are often interconnected with other activities, as well as the significance of alignment among the activities (Siggelkow, 2002). The fundamental 


\section{A Conceptual Development of a Business Model Typology in Tourism: the impact of digitalization and location Gabriel Linton and Christina Öberg}

reasoning is that there is no generic, single best way of organizing or executing business activities. Instead, firms can reach high performance when activities make a good fit with each other, and also fit with the specific business context. This is when an alignment between factors such as strategy and structure, together with different contextual factors such as technology or environment is achieved (Drazin \& Van de Ven, 1985).

Three different types of fit have been described in previous research (Drazin \& Van de Ven, 1985; Venkatraman, 1989). One type indicates how business model activities fit with strategy (Porter, 1996) by ensuring how the consistency between activities and strategy leads to competitive advantage (Spieth et al., 2016). A second type of fit refers to a business model dyad, when two different activities mutually reinforce one another (Milgrom \& Roberts, 1995). And, a third type of fit includes the business model architecture, which goes beyond bivariate investigations to take a configurational approach to optimizing the entire set of activities (Morris et al., 2005). The third is the type of fit that is adopted in this paper, which thereby includes contextual items as contingency factors. This type fits well with the holistic view of business models as it can elaborate on the many different factors that contribute to the overarching approach of a company's operations.

Our research focusing on configurations is not intended to be exhaustive, but rather to show important relationships, while we acknowledge that there are always many viable configurations which cannot be accounted for. By identifying some typical configurations, however, it is possible to go beyond the "one-variable-at-a-time" approach (Miller, 1996). This way the variables become meaningful as a collective rather than individually (Dess et al., 1993). Two related terms to configuration research, which also go beyond it, are typologies and taxonomies (Short et al., 2008). The difference between typologies and taxonomies is that typologies are based on theoretical types and are conceptually determined by the researcher, while taxonomies are classes (or kinds) that are found empirically and developed bottom-up (Baden-Fuller \& Morgan, 2010). The configurational approach would rather target the former, while variables selected for developed theoretical types are empirically grounded based on their relevance.

\subsection{Business models and configuration theory}

Configuration theory scholars have investigated companies by differentiating between many factors such as strategies, structures, processes, and decision-making styles (Burns \& Stalker 1961; Mintzberg, 1973; Miles \& Snow, 1978). A company's business model can be argued to reflect its strategy ( Shafer et al., 2005; CasadesusMasanell \& Ricart, 2010), and include its structure (Amit \& Zott, 2001). Several scholars have also implied the relevance of an activity or process perspective in studying business models (Morris et al., 2005; Johnson et al., 2008; Zott \& Amit, 2010). In addition, business models highlight a holistic and system-level approach in clarifying how companies operate their businesses (Zott et al., 2011). With a similar approach, configuration theory helps in explaining on a holistic system level how theoretical attributes fit with each other to achieve synergies (Miller, 1996). Configuration theory and business models hence consider similar factors and can therefore be argued to be a good match in terms of their theoretical constructs. This paper's conceptualization of business models as activity systems thus allows the adoption of content, structure and governance (Zott \& Amit, 2010) as the three theoretical attributes at the core of the configurations.

Research on business models has highlighted the need to take contingency factors into account (Saebi \& Foss, 2015; Pang et al., 2019), which is a fundamental part of configuration theory (Venkatraman, 1989). Although many different factors could be considered, this paper focuses on digitalization and company location as factors that will be discussed in more detail below.

\subsubsection{Digitalization}

Technology has been highlighted as a critical factor for business models (Pateli \& Giaglis, 2005), and also for tourism (Stamboulis \& Skayannis, 2003; Pantano \& Corvello, 2014). It has been considered an important contingency factor in management studies for decades (Woodward, 1965). Technology explains how digitalization has introduced recent changes in various sectors, including tourism (Boksberger \& Laesser, 2009; Laesser et al., 2009; Neuhofer et al., 2012; Koukopoulos \& Styliaras, 2013; Kubiak, 2014; Wernz et al., 2014). This explanation can entail technology in the form of a product, product offering, or production development (George \& Bock, 2011). Digitalization (Hull et al. 2007; Hair et al., 2012; Henfridsson et al., 2014; Tan \& MoralesArroyo, 2014), denotes the application of computer- 


\section{A Conceptual Development of a Business Model Typology in Tourism: the impact of digitalization and location Gabriel Linton and Christina Öberg}

based technology. In this paper, we focus on how digital solutions either replace current ways of operating businesses, or create a basis for new businesses. This in turn stresses the context of use rather than the technology as such, as recently seen in the sharing economy, for instance (Belk, 2014).

Digital solutions may support regular businesses, enable seamless intermediaries between present companies, or create entirely new businesses (Hull et al. 2007; Hair et al., 2012; Guthrie, 2014; Sussan \& Acs 2017). Dy et al. (2017) point at how digital solutions lower entry barriers to markets, create 'invisible' online markers, or serve to "disembody" the business by taking it online. Digitalization has traditionally affected marketing and sales (e-commerce, Guthrie, 2014; Hair et al., 2012), yet more recently has expanded to include organizing exchanges around platforms, which links increasingly more parties together and hence affects companies' abilities to develop and operate multiparty business models (Schweizer, 2005; Chesbrough, 2007; Zott \& Amit, 2013).

In tourism, the advancement of tourists using mobile phones has led to big changes in how tourists behave (Neuhofer et al., 2012), transitioning from "sit and search" to "roam and receive" (Pihlström, 2008). Digitalization has provided consumers with sources of information, user-generated content, and various forms of platforms for interaction (Neuhofer et al., 2012). The online booking systems, e-tourism, and platform-based businesses as referenced by Beritelli and Schegg (2016), Forgacs and Dimanche (2016), Kathan et al. (2016), and $\mathrm{Yu}$ (2016), all depart from digitalization in the sector.

\subsubsection{Destination location}

For tourism businesses, it has traditionally been important to be positioned close to tourism destinations to be able to interact with customers, while offering products and services for tourists. Brush et al. (2008) use the location of businesses as a factor in their configuration framework, and highlight that location choice is of importance in terms of access to the firm and availability of specific physical, infrastructural, and human resources. As well, efficiency and aesthetic factors such as accessibility (Prideaux, 2000) and attractiveness (Henderson, 2006) have been pointed to as important in tourism research. Nicolau and Más (2006) highlight the importance of distance when tourists select a destination. This includes physical distance from home destination and how infrastructure makes the destination accessible by, for example, roads and airports (Prideaux 2000; Riera 2000). This again means that rather than placing itself close to the tourist's residence, it is important to offer accessible experiences. This gives location a specific meaning for tourism, where tourism firms should place themselves close to accessible and attractive destinations.

If a location is suitable in terms of distance and accessibility for tourism, it can of course still be an unattractive destination for tourists. An attractive destination means that the place itself creates the reason for tourists to travel there (Kim \& Perdue, 2011). The availability of food and restaurant businesses, retail stores, golf courses, and cultural sites are some of the factors that make destinations attractive for tourists (Formica \& Uysal, 2006). Nonetheless, recent trends in tourism point at how previously unattractive destinations have tended to become attractive based on unique services and experiences offered, that is, the location's market value proposition and business model.

For example, amusement parks can turn a previously unattractive destination into an attractive one. Also, some hotels offer an experience that makes the hotel itself a destination, while e-tourism tends to blur any link between suitability and attractiveness as the tourist no longer travels to the destinations, but experiences them from home $(\mathrm{Yu}, 2016)$. Both options mean that digitalization has had an impact on the tourism location. Furthermore, digitalization in the tourism industry may mean that tourist firms will operate from "somewhere else" than the destination itself, as is the case with various intermediary tourism services. Likewise, with sharing economy platforms, for instance, as denoted in the business model typology developed in this paper.

\section{Research Design}

To conceptually develop a business model typology in tourism, this paper departs from a "chronological" development that starts in terms of business models that have existed for a long time, then moves on to more recent developments of business models in the sector. The focus of this research is on the activities pursued by tourism sector actors (Zott \& Amit, 2010), while also linking these with who performs the activities in singleparty or multiple-party settings (Zott \& Amit, 2013). We thus explore the main streams of development that have caused ongoing transformation of the sector, in 


\section{A Conceptual Development of a Business Model Typology in Tourism: the impact of digitalization and location Gabriel Linton and Christina Öberg}

particular, digitalization, new patterns of tourism, and the introduction of new players in the sector. We describe four possible business model configurations that customers are able to interact with that were identified in this process, and exemplify them below.

The four types of business models were analyzed in an iterative process (Bocken et al., 2014) through looking at the content, structure, and governance activities (Zott \& Amit, 2010). This allowed us to identify distinct differences among the four typical business models, while permitting modifications to the initially identified business models. In further analysis of the business models, their fit among activities (Morris et al., 2005) was captured through carefully studying the synergies among activities based on practical examples of each type of business model to conclude the four ideal types.

\section{Business Model Typologies in Tourism}

By integrating the considerations of digitalization and location, we developed a typology framework of different context settings for business models (Figure 1). This typology serves as a starting point to understand the fit (Miller \& Friesen, 1978). Fit for this typology is based on the fit between digitalization, the location of the destination, and the business model. Thus, different business models can be argued to fit well together depending on these two different factors, as elaborated below.

\subsection{Bricks and mortar business model}

Cell 1 is characterized by a suitable and attractive destination, when the tourist firm only modestly relies on digital solutions. The archetype for this setting is therefore the traditional bricks and mortar tourism business model, which depicts how various tourist firms locate themselves in attractive destinations, where the destinations themselves are the reason for tourists to travel there. This includes, for instance, the establishment of a hotel or restaurant in Paris or New York, two examples of destination cities. With this business model, it is thus key to be located close to or at an attractive destination, which brings the reinforcement of having proximity to supplementary establishments (for example, a restaurant being close to a hotel). The business model is based on suitable and attractive destinations (Prideaux, 2000; Henderson, 2006) and does not require digital capability.

Using Zott and Amit's (2010) operationalization of business models as activity systems, the content of the main activities of this type of business model can be seen as serving a classic tourism service (involving travel, accommodation and/or meals) to the tourist directly. The governance and linking of activities are all handled by a "focal" tourist firm (a single company such as the hotel owner or restaurant, whose focus is to manage the tourists' experience) and are predominantly done so through its choice of location. Finding fit between the activities, structures, and governance should be reasonably unproblematic, since it all falls within the

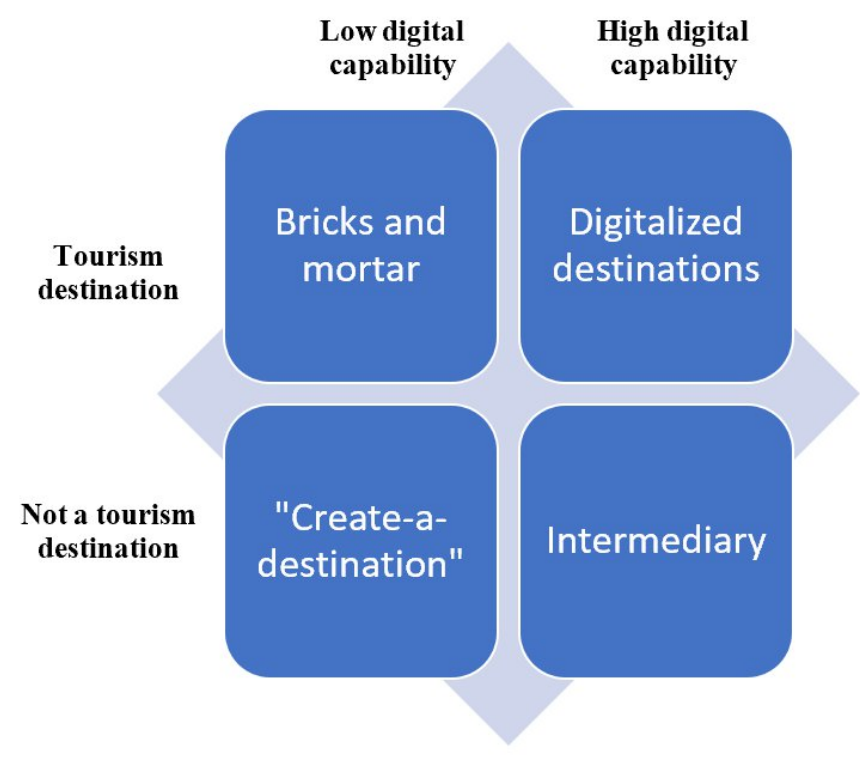

Figure 1. Tourism business models based on location and digitalization 


\section{A Conceptual Development of a Business Model Typology in Tourism: the impact of digitalization and location Gabriel Linton and Christina Öberg}

same focal firm (given that individual tourist firms act quite independently of one another). Well performed, the fit should lead to efficiencies and synergies. The contingency factor of an attractive location will also lead to considerable synergies of the business model as tourists will be attracted to the location, while it would be considerably difficult to reach fit with this type of business model if the tourist firm were not located close to an attractive destination.

\section{2 "Create-a-destination" business model}

"Create-a-destination" (lower left cell in Figure 1) is characterized by a tourism destination, where the firm has low to medium digital capability. The archetype for this setting is a "create-a-destination" business model, which denotes how tourist firms explore areas that would not normally attract any tourists (Barreda et al., 2016). Rather than locating to an attractive destination, the tourist firm creates that destination and does so geographically in an area reachable for consumers (that is, suitable for tourism). All of this is an integrated part of the experience and the destination would not attract tourists unless the tourist firm had been there.

The ice hotel outside of Jukkasjärvi, Sweden, is one example of this. The hotel is constructed totally of ice and gets rebuilt with different designs every year. Activities integrated with the hotel visit include hot tub bathing and ice sculpting, for instance, along with the hotel itself as a tourist attraction. Other examples of experience-based business models are amusement parks (for example, Disneyland).

The content of the main activities of this type of business model (Zott \& Amit, 2010) is the concept of an integrated service offering that constitutes an entire tourism experience. This refers to how hotels, restaurants, and tourist attractions built by different owners or business partners, co-located as a way to create an attractive shared destination, where the tourist consumes multiple elements as one offering. The tourism activities are thereby expanded to include a unique experience.

Compared to the bricks and mortar business model, the create-a-destination model requires more activities that are linked and structured by a focal firm, and (possibly) coordinated with local business partners (Chesbrough, 2007). Governance of these businesses can vary, but the core of the service would often be offered directly by the focal firm, while unique value proposition would require co-produced activities with, for example, artists, architects, and adventure experts. The location's contingency factor being suitability it is important to make it an attractive destination, as well as having a variety of suitable complementary actors colocating to create attractive choices for the tourists.

\subsection{Digitalized destinations business model}

A digitalized destination business model (upper right cell in Figure 1) refers to a destination where the tourism firm has digital capability. The focus for the archetype in this setting is a business model that relies on highly advanced tourism experiences and includes technology at the destination, sometimes referred to as "smart tourism". This contains technology advancements that make use of such things as sensors, big data, near-realtime real-world data, visualization, and new ways of connectivity (Gretzel et al., 2015), including digitallymediated tourism experiences, which are enhanced through context awareness and personalization (Buhalis \& Amaranggana, 2015). The archetype for this model is not yet well established, but with the rapid digital development of tourism destinations, its transformation continues to be vital in the near future (Koukopoulos \& Styliaras, 2013). Better informed, connected, and engaged tourists who can interact at the destination in new ways will provide new and enhanced tourism experiences.

The critical activities of this archetype (Zott \& Amit, 2010) are focused on gathering data from users (big data or data from sensors), then analyzing and presenting it (visualization).They are also concerned with the creation of a seamless experience for the tourist (Hull et al. 2007; Hair et al. 2012; Guthrie 2014; Sussan \& Acs 2017), including the connection of various digital systems with real life tourism experiences.

The structure of this type of business model requires that all activities be highly linked among various actors in a way that enables a seamless and user-friendly experience. Governance in this business model is expected to be highly distributed among different actors that specialize in a niche technology area (for example, collecting data through sensors may be performed by one firm, while analyzing the data may be performed by another firm, and how the data is used may not even be known by those providing it). The digital capability of a company with its combined physical and human resources is the vital contingency factor for this type of business model. 


\section{A Conceptual Development of a Business Model Typology in Tourism: the impact of digitalization and location Gabriel Linton and Christina Öberg}

\subsection{Intermediary business model}

The intermediary business model (lower right cell in Figure 1) means that the company does not have to be located where tourists travel, yet can still be involved in tourism activities. This type of business model can be described as a location that is not necessarily a tourism destination itself, and where the digital capability of the firm is high. This archetype includes P2P and online business models. The tourism firm here operates as an intermediary platform (Riemer et al., 2017) between the destination and the tourist.

Tourism platforms include online booking sites, which become more popular as tourists freely choose among alternatives and become their own travel agencies by directly selecting hotels, flights, and so on (de Carlos et al., 2016), and also P2P exchanges. Examples of booking sites include Booking.com and TripAdvisor, which act either as intermediaries between traditional tourist firms and tourists, or among tourists. The P2P setting (Belk, 2014) refers to how consumers appear as both producers and users in the business model, enabled through platform technology (Sigala, 2017).

This type of business model has introduced entirely new actors into tourism sectors as platform operators, intermediaries, and service providers. Its conceptualization has led established parties in the sector to adapt these business models (Geissinger et al., 2017). In addition to introducing new actors and thereby affecting competition in the tourism sector, P2P business models also modify current concepts and configurations. The lodging provided through Airbnb (Forgacs \& Dimanche, 2016; Kathan et al., Veider 2016), for instance, includes how the tourist may interact with the accommodation's owners (Richard \& Cleveland, 2016; Johnson \& Neuhofer, 2017; Mao \& Lyu, 2017). The typical example here is the sharing economy platform Airbnb (Wegmann \& Jiao, 2017), but this type of business model includes many variants, such as Vayable, a platform for personal tour guides. The main activity of this type of business model is to link tourists with an offer that the tourist is willing to buy.

There are several critical activities associated with this type of business model: attracting service providers and users to a two-sided platform, the platform's role as an intermediary linking providers and users together, and providing a form a security (for example, through holding payments and collecting reviews; Ert et al., 2016). The structure of activities (Zott \& Amit, 2010) needs to be linked with basically instant interaction (for example, tourists asking providers about availability through the platform, and then making an instant booking). The governance model is distributed so that the focal firm - the platform - connects and secures transactions, which enables the service providers to freely offer their services. The contingency factor is the digital capability of a company and the number of service providers and tourists needed to create an attractive and sustainable link between the offerings and their consumers (Chesbrough, 2007).

\section{Discussion}

Rather than aiming for a one-fit-all business model for tourism, the study follows a configurational approach and the notion of "equifinality" (Fiss, 2007, 2011), which implies that there are many different paths to the same business goal (for example, high performance). In line with this, the paper suggests that there are several different tourism business models.

The configurational approach to business models accentuates the importance of holistic context interactions (Porter \& Siggelkow, 2008). Research on business models has been, in general, too often absent from contextualization. This paper argues that it is not only about matching business models with the tourism sector, but also about taking contextual factors into consideration. In this study, location and digitalization are highlighted as important contextual factors in the tourism sector for the development of business models. The increased digitalization of businesses, including the introduction and growth of the sector's sharing economy, points at the dynamics of such contextual factors, and the need for firms to adapt to ever new circumstances, as well as to redefine location. By combining several factors of business model activities with the contextual factors of location and digitalization, knowledge about business models can be enhanced compared to researching these factors in isolation or describing business models generally.

The various business model archetypes indicate how activities are performed by multiple independent (for example, the bricks and mortar business model) or highly integrated tourist firms (for example, the create-adestination business model). Digitalization is linked in business models to the introduction of new actors, including intermediary business models, and the construction of destination interactions, such as smart tourism. New actors combined with business network integration put focus on the importance of business 


\section{A Conceptual Development of a Business Model Typology in Tourism: the impact of digitalization and location Gabriel Linton and Christina Öberg}

partnering and shared stewardship of resources.

In comparing intermediary business models with create-a-destination business models, for instance, the create-a-destination model requires coordination among tourist firms, while in intermediary business models, coordination is only accomplished by the intermediary firm itself, mediated by digital solutions. Thus, the density of interactions is more limited, while the number of actors is higher, and trust is also given a different meaning as it is not based on social interactions, but rather on digitally coordinated experiences (Möhlmann, 2015), including travel advice and evaluations shared among peers.

Local presence and type of business vary across different business models. Bricks-and-mortar and create-a-destination business models need local presence to function, while in intermediary business models, the focal firm does not (necessarily) have to have a local presence. A digital destination is either based on a local destination presence, or on firms operating remotely to the tourism destination. The extreme here is e-tourism with "tourists" not even visiting the tourism destination. Intermediary business models can be seen as enablers for other businesses that accentuates the role of intermediaries, while the other business models provide core values for the tourist. Therefore, it is important to note that these different archetypes of business models may well coexist and even mutually assist one another. The archetypes should therefore be seen as typical, rather than as exhaustive or non-combinable. Attractive destinations (such as a city) can be one important factor, but the experience of a unique hotel in an attractive destination can add to the whole experience, thereby becoming a hybrid configuration.

\section{Conclusions}

Based on a configurational approach (Meyer et al., 1993; Miller, 1996), we created a theoretically derived typology of tourism business models, which includes four different archetypes. The archetypes are each connected with different contextual settings: (1) bricksand-mortar business models, where single actors perform distinct and separate activities linked to attractive destinations, (2) create-a-destination business models, which include making an unattractive destination attractive, (3) digitalized business models, which use devices to enhance experiences and provide e-tourism and smart tourism, for instance, and (4) intermediary business models that put focus on digital solutions to connect tourists with current and new actors and tourism destinations.

The paper highlights the impact of contextual factors, in terms of suitable and unsuitable locations (Prideaux, 2000), as well as attractive and unattractive destination locations (Kim \& Perdue, 2011). Moreover, we incorporated the influence of digitalization as a trend currently disrupting tourism in the typology (Stamboulis \& Skayannis, 2003). The four business models follow but are also part of creating - transformational trends in the tourism sector, which includes new parties entering the tourism sector (for example, intermediaries and peers), digitalization (enabler for online and P2P operations), and new consumption patterns (focusing both on more active tourists and how tourists arrange their travelling more independently through sites and apps) (Boksberger \& Laesser, 2009; Laesser et al., 2009; Koukopoulos \& Styliaras, 2013; Kubiak, 2014; Wernz et al., 2014). Importantly though, the different business models continue to exist side-by-side, while research increasingly has turned its focus to, for instance, sharing economy business models as entering and transforming the tourism sector (Gutierrez et al., 2017). Tourism business models may well complement one another locally or at a distance, and thereby be integrated or create value-added interactions among parties.

\subsection{Theoretical contribution}

The main theoretical contribution of this paper is identifying a typology for tourism business models. Previous researchers have described various business models and ways to operate businesses in the sector, as well as marked the importance of understanding business models in the sector (Brannon \& Wiklund, 2014). We believe this paper might be the first to actually present a typology.

The uniqueness of the tourism sector, with location as a main business characteristic, together with its rapid digitalization, means that this typology is sector-specific, while also contemporary. With theoretical grounding in a configuration approach, it takes the two factors of location and digitalization in the tourism sector into account, thereby deriving a new way of classifying tourism business models. The four business models highlighted that there is a wide diversity of tourism firms, and the classification enables future tourism research to be conducted in new ways. Moreover, the paper takes a fresh approach to the theoretical grounding of business models by basing them on a 


\section{A Conceptual Development of a Business Model Typology in Tourism: the impact of digitalization and location Gabriel Linton and Christina Öberg}

configurational approach. This contribution goes beyond the tourism sector and can be used for research on business models in other sectors or industries, perhaps through modifying the dimension of location to other factors central for the specific sector or industry.

\subsection{Managerial implications}

For managers, location and digitalization as outlined in Figure 1 point out how certain combinations are more fruitful than others, and how a firm may create an attractive location as long as it is suitable for tourism. For a tourist firm, the business model typology hence becomes a tool to consider alternative options, while also considering (present and upcoming) competitors' business models. Specific questions to address are: How suitable and/or attractive is the destination for tourism? What is needed to increase the attractiveness of the destination? How can this be accomplished by the firm and/or collaboration partners? What capabilities are needed to make it more attractive? How might digital solutions affect the business model? And what about the competition? It is also important that business model configuration does not get "stuck in the middle" between different archetypes (Porter, 1980), or fail to support the key activities to be performed. This means to draw attention to the contingency factors of attractiveness, location, and digital capabilities as noted in relation to each business model above.

\subsection{Further research}

This paper is conceptual, and therefore future empirical studies can investigate the occurrence of these business models in the tourism sector by surveying the sector. Detailed empirical studies, which investigate the forces that move business models toward or away from fit would also enhance our understanding of business models in the tourism sector.

A weakness of configuration theory is its general inability to establish temporal stability. Therefore, a further research idea would be to investigate the dynamics of tourism business models following from changes in context over time, and thereby exploring the potential need for modifications of the business model to maintain fit (business modelling). Also, foresight studies may be applied to capture actors in the sector and their thoughts about the future, and thus open interesting new paths for future research.

\section{References}

Amit, R., \& Zott, C. 2001. Value creation in E business. Strategic Management Journal, 22: 493-520.

Baden-Fuller, C., \& Morgan, M.S. 2010. Business models as models. Long Range Planning, 43 (2-3): 156-171.

Beritelli, P., \& Schegg, R. 2016. Maximizing online bookings through a multi-channel-strategy: Effects of interdependencies and networks. International Journal of Contemporary Hospitality Management, 28 (1): 68-88.

Bocken, N.M.P., Short, S.W., Rana, P., \& Evans, S. 2014. A literature and practice review to develop sustainable business model archetypes. Journal of Cleaner Production, 65: 42-56.

Boksberger, P.E., \& Laesser, C. 2009. Segmentation of the senior travel market by the means of travel motivations. Journal of Vacation Marketing, 15 (4): 311-322.

Brannon, D.L., \& Wiklund, J. 2014. 10 tourism and business model innovation: the case of us wine makers. Handbook of Research on Innovation in Tourism Industries: 228-248.

Brush, C.G., Edelman, L.F., \& Manolova, T.S. 2008. The effects of initial location, aspirations, and resources on likelihood of first sale in nascent firms. Journal of Small Business Management, 46 (2): 159-182.

Buhalis, D., \& Amaranggana, A. 2015. Smart tourism destinations enhancing tourism experience through personalisation of services. Information and Communication Technologies in Tourism, Springer, Cham: 377-389.

Burger, B., \& Fuchs, M. 2005. Dynamic pricing - A future airline business model. Journal of Revenue and Pricing Management, 4 (1): 39-53.

Burns, T., \& Stalker, G.M. 1961. The Management of Innovation. University of Illinois at UrbanaChampaign's Academy for Entrepreneurial Leadership Historical Research Reference in Entrepreneurship.

Casadesus-Masanell, R., \& Ricart, J.E. 2010. From strategy to business models and onto tactics. Long Range Planning, 43 (2): 195-215.

Chesbrough, H. 2007. Business model innovation: it's not just about technology anymore. Strategy \& Leadership, 35: 12-17.

Chesbrough, H., \& Schwartz, K. 2007. Innovating business models with co-development partnerships. Research-Technology Management, 50 (1): 55-59.

d'Angella, F., Carlo, M.D., \& Sainaghi, R. 2010. Archetypes of destination governance: a comparison of international destinations. Tourism Review, 65(4): 61-73.

de Carlos, P., Araújo, N., \& Fraiz, J.A. 2016. The new intermediaries of tourist distribution: Analysis of online accommodation booking sites. International 


\section{A Conceptual Development of a Business Model Typology in Tourism: the impact of digitalization and location Gabriel Linton and Christina Öberg}

Journal of Management Science \& Technology Information, 19: 39-58.

Demil, B., \& Lecocq, X. 2010. Business model evolution: In search of dynamic consistency. Long Range Planning, 43 (2): 227-246.

Dess, G.G., Newport, S., \& Rasheed, A.M.A. 1993. Configuration research in strategic management: Key issues and suggestions. Journal of Management, 19 (4): 775-795.

Drazin, R., \& Van de Ven, A.H. 1985. Alternative forms of fit in contingency theory. Administrative Science Quarterly, 30 (4): 514-539.

Dy, A.M., Marlow, S., \& Martin, L. 2017. A web of opportunity or the same old story? Women digital entrepreneurs and intersectionality theory. Human Relations, 70 (3): 286-311.

Ert, E., Fleischer, A., \& Magen, N. 2016. Trust and reputation in the sharing economy: The role of personal photos in Airbnb. Tourism Management, 55: 62-73.

Fiss, P.C. 2007. A set-theoretic approach to organizational configurations. Academy of Management Review, 32: 1180.

Fiss, P.C. 2011. Building better causal theories: A fuzzy set approach to typologies in organization research. Academy of Management Journal, 54 (2): 393-420.

Forgacs, G., \& Dimanche, F. 2016. Revenue challenges for hotels in the sharing economy: facing the Airbnb menace. Journal of Revenue and Pricing Management, 15 (6): 509-515.

Formica, S., \& Uysal, M. 2006. Destination attractiveness based on supply and demand evaluations: An analytical framework. Journal of Travel Research, 44 (4): 418-430.

Foss, N.J., \& Saebi, T. 2017. Business models and business model innovation: Between wicked and paradigmatic problems. Long Range Planning, 51(1): 9-21.

Gardiner, S., \& Scott, N. 2018. Destination innovation matrix: A framework for new tourism experience and market development. Journal of Destination Marketing \& Management, 10: 122-131.

Geissinger, A., Laurell, C., \& Öberg, C. 2017b. Sharing the sharing economy idea - On the imitation of business models in the case of Airbnb. 4th International Workshop on the Sharing Economy, Lund.

George, G., \& Bock, A.J. 2011. The business model in practice and its implications for entrepreneurship research. Entrepreneurship Theory and Practice, 35 (1): 83-111.

Gretzel, U., Sigala, M., Xiang, Z., \& Koo, C. 2015. Smart tourism: foundations and developments. Electronic Markets, 25 (3): 179-188.
Guthrie, C. (2014), The digital factory: A hands-on learning project in digital entrepreneurship. Journal of Entrepreneurship Education, Arden, 17 (1): 115-133.

Gutiérrez, J., García-Palomares, J.C., Romanillos, G., \& Salas-Olmedo, M.H. 2017. The eruption of Airbnb in tourist cities: Comparing spatial patterns of hotels and peer-to-peer accommodation in Barcelona. Tourism Management, 62: 278-291.

Hair, N., Wetsch, L.R., Hull, C.E., Perotti, V., \& Hung, Y.T.C. 2012. Market orientation in digital entrepreneurship: advantages and challenges in a web 2.0 networked world. International Journal of Innovation and Technology Management, 9 (6): 125145.

Heilbron, J., \& Casadesus-Masanell, R. 2015. The business model: Nature and benefits. Business Models and Modelling, 33: 3-30.

Henderson, J.C. 2006. Tourism in Dubai: overcoming barriers to destination development. International Journal of Tourism Research, 8 (2): 87-99.

Henfridsson, O., Mathiassen, L., \& Svahn, F. 2014. Managing technological change in the digital age: the role of architectural frames. Journal of Information Technology, 29 (1): 27-43.

Hull, C.E., Hung, Y.-T.C., Hair, N., Perotti, V., \&DeMartino, R. 2007. Taking advantage of digital opportunities: a typology of digital entrepreneurship. International Journal of Networking and Virtual Organisations, 4 (3): 290-303.

Johnson, A.-G., \& Neuhofer, B. 2017. Airbnb - an exploration of value co-creation experiences in Jamaica. International Journal of Contemporary Hospitality Management, 29 (9): 2361-2376.

Johnson, M.W., Christensen, C.M., \& Kagermann, H. 2008. Reinventing your business model. Harvard Business Review, 57: 51-59.

Kathan, W., Matzler, K., \& Veider, V. 2016. The sharing economy: Your business model's friend or foe? Business Horizons, 59 (6): 663-672.

Kim, D., \& Perdue, R.R. 2011. The influence of image on destination attractiveness. Journal of Travel \& Tourism Marketing, 28 (3): 225-239.

Koukopoulos, D., \& Styliaras, G. 2013. Design of trustworthy smartphone-based multimedia services in cultural environments. Electronic Commerce Research, 13 (2): 129-150.

Krizaj, D., Brodnik, A., \& Bukovec, B. 2014. A tool for measurement of innovation newness and adoption in tourism firms. International Journal of Tourism Research, 16 (2): 113-125.

Kubiak, B.F. 2014. Model of strategic information in support of business processes of the tourism industry. Business Informatics, 16 (2): 113-125. 


\section{A Conceptual Development of a Business Model Typology in Tourism: the impact of digitalization and location Gabriel Linton and Christina Öberg}

Laesser, C., Beritelli, P., \& Bieger, T. 2009. Solo travel: Explorative insights from a mature market (Switzerland). Journal of Vacation Marketing, 15 (3): 217-227.

Magretta, J. 2002. Why business models matter. Harvard Business Review, 80: 86-93.

Mangematin, V., \& Baden-Fuller, C. (Eds.). 2015. Introduction: Business models and modelling business models. Business Models and Modelling, 33: xi-Xxii.

Mao, Z., \& Lyu, J. 2017. Why travelers use Airbnb again? An integrative approach to understanding travelers' repurchase intention. International Journal of Contemporary Hospitality Management, 29 (9): 24642482 .

Martins, L.L., Rindova, V.P., \& Greenbaum, B.E. 2015. Unlocking the hidden value of concepts: A cognitive approach to business model innovation. Strategic Entrepreneurship Journal, 9 (1): 99-117.

McGrath, R.G. 2010. Business models: A discovery driven approach. Long Range Planning, 43 (2): 247261.

Meyer, A.D., Tsui, A.S., \& Hinings, C.R. 1993. Configurational approaches to organizational analysis. Academy of Management Journal, 36: 11751195.

Miles, R.E., \& Snow, C.C. 1978. Organizational strategy, structure, and process. New York: McGraw-Hill.

Milgrom, P., \& Roberts, J. 1995. Complementarities and fit strategy, structure, and organizational change in manufacturing. Journal of Accounting and Economics, 19: 179-208.

Miller, D. 1996. Configurations revisited. Strategic Management Journal, 17 (7): 505-512.

Miller, D., \& Friesen, P.H. 1978. Archetypes of strategy formulation. Management Science, 24 (9): 921-933.

Mintzberg, H. 1973. Strategy-making in three Modes. California Management Review, 16 (2): 44.

Möhlmann, M. 2015. Collaborative consumption: determinants of satisfaction and the likelihood of using a sharing economy option again. Journal of Consumer Behaviour, 14 (3): 193-207.

Molina-Castillo, F.J., Meroño-Cerdan, A.L., \& LópezNicolás, C. 2019. Impact of business model objectives on marketing innovation activities: A comparison between manufacturing and service firms. European Journal of Innovation Management, 23 (1): 177-195.

Morris, M., Schindehutte, M., \& Allen, J. 2005. The entrepreneur's business model: toward a unified perspective. Journal of Business Research, 58: 726-735.

Neuhofer, B., Buhalis, D., \& Ladkin, A. 2012. Conceptualising technology enhanced destination experiences. Journal of Destination Marketing \& Management, 1: 36-46
Nicolau, J.L., \& Más, F.J. 2006. The influence of distance and prices on the choice of tourist destinations: The moderating role of motivations. Tourism Management, 27 (5): 982-996.

Osterwalder, A., Pigneur, Y., \& Tucci, C.L. 2005. Clarifying business models: Origins, present, and future of the concept. Communications of the Association for Information Systems, 16: 1-25.

Pang, C., Wang, Q., Li, Y., \& Duan, G. 2019. Integrative capability, business model innovation and performance: Contingent effect of business strategy. European Journal of Innovation Management, 22(3): 541-561.

Pantano, E., \& Corvello, V. 2014. Tourists' acceptance of advanced technology-based innovations for promoting arts and culture. International Journal of Technology Management, 64(1): 3-16.

Pateli, A.G., \& Giaglis, G.M. 2005. Technology innovation induced business model change: a contingency approach. Journal of Organizational Change Management, 18 (2): 167-183.

Pihlström, M. 2008. Perceived value of mobile service use and its consequences. Helsinki: Hanken.

Porter, M., \& Siggelkow, N. 2008. Contextuality within activity systems and sustainability of competitive advantage. Academy of Management Perspectives, 22 (2): 34-56.

Porter, M.E. 1980. Competititve Strategy. New York: Free Press.

Porter, M.E. 1996. "What is Strategy?" Harvard Business Review, 74 (6): 61-78.

Prideaux, B. 2000. The role of the transport system in destination development. Tourism Management, 21 (1): 53-63.

Richard, B., \& Cleveland, S. 2016. The future of hotel chains: Branded marketplaces driven by the sharing economy. Journal of Vacation Marketing, 22 (3): 239248.

Riemer, K., Gal, U., Harnann, J., Gilchriest, B., \& Teixeira, M. (2017). Digital disruptive intermediaries: Finding new digital opportunities by disrupting established business models. Sydney: The University of Sydney Business School/Cap Gemini.

Riera, A. 2000. Modelos de elección discreta y coste del viaje. los espacios naturales protegidos en Mallorca. Revista de Economía Aplicada, VIII (24). Available at: http://www.redalyc.org/resumen.oa?id=96917630006 (accessed 12 August 2017).

Saebi, T., \& Foss, N.J. 2015. Business models for open innovation: Matching heterogeneous open innovation strategies with business model dimensions. European Management Journal, 33 (3): 201-213.

Scheepens, A.E., Vogtländer, J.G., \& Brezet, J.C. 2016. Two life cycle assessment (LCA) based methods to analyse and design complex (regional) circular 


\section{A Conceptual Development of a Business Model Typology in Tourism: the impact of digitalization and location Gabriel Linton and Christina Öberg}

economy systems. Case: making water tourism more sustainable. Journal of Cleaner Production, 114: 257268.

Schweizer, L. 2005. Concept and evolution of business models. Journal of General Management, 31 (2): 3756.

Shafer, S.M., Smith, H.J., \& Linder, J.C. 2005. The Power of Business Models. Business Horizons, 48: 199-207.

Short, J.C., Payne, G.T., \& Ketchen, D.J. 2008. Research on organizational configurations: Past accomplishments and future challenges. Journal of Management, 34 (6): 1053-1079.

Siggelkow, N. 2002. Evolution toward fit. Administrative Science Quarterly, 47 (1): 125-159.

Spieth, P., Schneckenberg, D., \& Matzler, K. 2016. Exploring the linkage between business model (\&) innovation and the strategy of the firm. $R \& D$ Management, 46 (3): 403-413.

Stamboulis, Y., \& Skayannis, P. 2003. Innovation strategies and technology for experience-based tourism. Tourism Management, 24 (1): 35-43.

Sussan, F., \& Acs, Z.J. 2017. The digital entrepreneurial ecosystem. Small Business Economics, 49 (1): 55-73.

Tan, M., \& Morales-Arroyo, M. 2013. Understanding distributional disruptions in the Interactive Digital Media eco-system. International Journal of Electronic Business, 11 (1): 42-62.

Taran, Y., Nielsen, C., Montemari, M., Thomsen, P., \& Paolone, F. 2016. Business model configurations: a five-V framework to map out potential innovation routes. European Journal of Innovation Management, 19(4): 492-527.

Teece, D.J. 2010. Business models, business strategy and innovation. Long Range Planning, 43: 172-194.

Venkatraman, N. 1989. The concept of fit in strategy research: Toward verbal and statistical correspondence. Academy of Management Review, 14 (3): 423-444.

Wegmann, J., \& Jiao, J. 2017. Taming Airbnb: Toward guiding principles for local regulation of urban vacation rentals based on empirical results from five US cities. Land Use Policy, 69: 494-501.

Wernz, C., Wernz, P.T., \& Phusavat, K. 2014. Service convergence and service integration in medical tourism. Industrial Management \& Data Systems, 114 (7): 1094-1106.

Woodward, J. 1965. Industrial Organization: Theory and practice. London: Oxford U.P.

$\mathrm{Yu}$, C.-C. 2016. A value-centric business model framework for managing open data applications. Journal of Organizational Computing and Electronic Commerce, 26 (1-2): 80-115.

Zach, F. 2012. Partners and innovation in American destination marketing organizations. Journal of Travel Research, 51 (4): 412-425.
Zach, F., \& Racherla, P. 2011. Assessing the value of collaborations in tourism networks: A case study of Elkhart County, Indiana. Journal of Travel \& Tourism Marketing, 28 (1): 97-110.

Zott, C., \& Amit, R. 2010. Business model design: An activity system perspective. Long Range Planning, 43 (2-3): 216-226.

Zott, C., \& Amit, R. (2013). The business model: A theoretically anchored robust construct for strategic analysis. Strategic Organization, 11 (4): 403-411.

Zott, C., Amit, R., \& Massa, L. 2011. The business model: Recent developments and future research. Journal of Management, 37: 1019-1042.

\section{About the Authors}

Gabriel Linton is Assistant Professor at Örebro University School of Business. His research interest include entrepreneurship in firms and startups and also entrepreneurship education. He also conducts research on innovation processes as well as regional innovation. The topic of relationships between firms is also of interest. Gabriel has published in journals such as: Journal of Business Research, $R \& D$ Management, Industrial Marketing Management, and European Journal of Innovation Management. He serves as a member of the Editorial Review Board for the Journal of Small Business and Entrepreneurship.

Christina Öberg is Professor/Chair in Marketing at Örebro University, Visiting Professor at Leeds University and associated with the Ratio Institute, Stockholm. She received her Ph.D. in industrial marketing from Linköping University. Her research interests include mergers and acquisitions, brands and identities, customer relationships, and innovation management. She has previously published in such journals as Journal of Business Research, European Journal of Marketing, International Marketing Review, and Industrial Marketing Management.

Citation: Linton, G. and Öberg, C. 2020. A Conceptual Development of a Business Model Typology in Tourism: the impact of digitalization and location. Technology Innovation Management Review, 10(7): 16-27.

http://doi.org/10.22215/timreview/1372

digitalization, location, technology, tourism, typology. 